\title{
The best correlation of the new index of hyperandrogenism with the grade of increased body hair
}

\author{
D Cibula, M Hill ${ }^{1}$ and L Starka ${ }^{1}$ \\ Department of Obstetrics and Gynecology, Apolinarska 18, Prague 2, 120 00, Czech Republic and ${ }^{1}$ Institute of Endocrinology, Narodni 8, \\ Prague 1, 110 00, Czech Republic
}

(Correspondence should be addressed to D Cibula; Email: david.cibula@iol.cz)

\begin{abstract}
Objective: Hyperandrogenemia is the most frequent endocrine disorder in fertile women causing a variety of negative metabolic disturbances. Establishing the diagnosis of androgen overproduction has important implications for the follow-up and treatment of patients. The aim of our study was to identify the optimal laboratory marker of androgen production by correlating the markers to the presence or grade of increased body hair as a clinical sign of hyperandrogenism.

Design: Prospective observational study.

Methods: A total of 62 women with acne were included into the study. The serum concentrations of testosterone, androstenedione, dehydroepiandrosterone (DHEA), DHEA sulfate (DHEAS) and sex hormone-binding globulin (SHBG) were evaluated. The index of free testosterone (IFT) and a new index of hyperandrogenism (IHA) were calculated. The monitored laboratory markers were correlated to the presence or grade of increased body hair using several statistical methods.

Results: The statistical significance of differences between the average levels of laboratory markers between hirsute and non-hirsute women decreased in the following order: IHA, androstenedione and DHEA. Of all the above laboratory markers, only increased IHA was present significantly more often in hirsute women. The significance of correlation between the grade of increased body hair and the tested variables decreased in the following order: IHA, IFT, DHEA, androstenedione, DHEAS and testosterone. Conclusions: The clinical marker of hyperandrogenism correlates most closely to IHA, reflecting the levels of all commonly determined androgens or androgen precursors and SHBG. Its simple calculation makes IHA a suitable tool for determining total production of androgens in clinical practice, especially in cases with borderline elevations of values.
\end{abstract}

European Journal of Endocrinology 143 405-408

\section{Introduction}

Hyperandrogenemia is the most frequent endocrine disorder in women of fertile age. Increased androgen production causes a variety of well-documented negative metabolic changes $(1-8)$. As a result, these women are at substantially higher risk of hypertension, coronary artery disease and non-insulin dependent diabetes mellitus (9-11). Moreover, many studies have demonstrated the hereditary nature of the underlying disturbance of steroidogenesis (12-15). This makes establishing the diagnosis of hyperandrogenism important from the clinical point of view and has implications for future treatment and follow-up of the patient.

Compared with other endocrinopathies, the diagnosis of hyperandrogenism is not based on the finding of decreased or increased levels of a single hormone. The dynamic test is not useful for the diagnosis either. Many laboratory markers or clinical signs are used in the evaluation of androgen production. The most often reported parameter is the level of testosterone or the index of free testosterone (IFT). However, increased levels of androstenedione or other androgen precursors (in many cases highly exceeding reference limits) is the only finding in many patients. Moreover, the fact as to whether the levels of androgens are close to the upper or lower reference value may be of importance.

The aim of our study was to identify the optimal laboratory marker for evaluation of androgen production. Besides the commonly monitored androgens and IFT, the value of a new index of hyperandrogenism (IHA) was calculated. The grade of increased body hair was chosen as a clinical marker of hyperandrogenism. The relationship between selected laboratory markers and the presence of hirsutism or grade of increased body hair was then established. 


\section{Subjects and methods}

Altogether, 62 women examined consecutively in an outpatient unit for acne vulgaris over the years 1998-1999 were included in the study. The inclusion criteria were age over 17 years and absence of systemic therapy over the past 6 months. Four patients, who fulfilled the diagnostic criteria for late-onset adrenocortical hyperaplasia during a shortened adrenocorticotropin (ACTH) test, were excluded from the study. All women participating in the study gave their informed consent. The ethics committee approved the study.

Increased body hair was graded using the method of Ferriman \& Gallwey (16). Hirsutism was defined as a Ferriman-Gallwey score (FG-score) greater than 8 . Blood was collected from all women in the early follicular phase, i.e. between days 3 and 6 of the menstrual cycle. The collections were made between 09.00 and $12.00 \mathrm{~h}$. If spontaneous menstrual bleeding failed to occur until day 45 of the cycle, bleeding was induced by progesterone administration. The following parameters were evaluated: serum levels of testosterone (T), androstenedione (ADION), dehydroepiandrosterone (DHEA), DHEA sulfate (DHEAS) and sex hormonebinding globulin (SHBG). Based on the level of total testosterone and SHBG, the IFT was calculated: $(\mathrm{IFT}=100 \times \mathrm{T} \quad(\mathrm{nmol} / \mathrm{l}) / \mathrm{SHBG} \quad(\mathrm{nmol} / \mathrm{l})) . \quad$ The IHA reflecting the levels of all monitored hormones was calculated according to the following formula:

$$
I H A=\sqrt[5]{(I F T \cdot A D I O N \cdot D H E A \cdot D H E A S)}
$$

(The fifth root in the formula was chosen for the best approximation to Gaussian data distribution enabling the utilization of simple statistical methods.)

A shortened ACTH test was performed to exclude late-onset adrenocortical hyperplasia.

The levels of luteinizing hormone, follicle-stimulating hormone and testosterone were determined by chemiluminiscent assay using an ACS:180 autoanalyzer (Bayer Diagnostics, Munchen, Germany). The levels of DHEA, DHEAS and androstenedione were established using radioimmunoassay methods (Immunotech, IOT, Marseille, France).

The reference values for normal levels were as follows: testosterone $0.5-2.63 \mathrm{nmol} / \mathrm{l}$, androstenedione $1.57-5.4 \mathrm{nmol} / \mathrm{l}$, DHEA $0.8-10.5 \mu \mathrm{g} / \mathrm{l}$, DHEAS $2.4-$ $14.5 \mu \mathrm{mol} / \mathrm{l}$ and SHBG 43.2-96.0 $\mathrm{nmol} / \mathrm{l}$.

\section{Statistical analysis of data}

The box-whisker plot, scatter plot, quantile plot and normal probability plot were used for outlier detection and for evaluating data distribution. Power transformation was applied to improve the distribution of the skewed data.

Treated data were processed by the following statistical procedures. (A) The two-sample comparison test was performed to evaluate the significance of differences in the mean values of laboratory markers between the groups of non-hirsute and hirsute women. (B) Fischer's exact test was used for the analysis of the relation between the frequency of patients with normal and elevated values of laboratory markers and the frequency of non-hirsute and hirsute women. (C) Receiver operating characteristics (ROC) graphs were used for plotting the true positivity against the false positivity of the tested markers. The maximum likelihood ratio was used for the determination of the optimum cut-off values in IHA (statistical software NCSS 2000; NCSS, Kaysville, UT, USA). The original laboratory cut-off values were used for the remaining markers. (D) The correlations between the FG-score and laboratory markers were evaluated by Spearman's rank correlation test.

\section{Results}

A statistical summary of the group is shown in Table 1. Statistical significance of differences between the means of laboratory markers in hirsute and nonhirsute women decreased in the following order: IHA $(P<0.006)$, androstenedione $(P<0.017)$ and DHEA $(P<0.043)$. The differences in DHEAS $(P<0.085)$, IFT $(P<0.092)$, SHBG $(P<0.096)$ and testosterone $(P<0.270)$ were insignificant.

The upper reference value for IHA determined from ROC graphs was 5.58. Fischer's exact test showed a significant difference in the presence of hirsutism only between women with normal and elevated IHA $(P<0.05)$ (Table 2). The difference was absent in the other laboratory markers.

The significance of correlations between the FG-score and the tested variables decreased in the following order: IHA $(\mathrm{R}=0.476, P<0.0002)$, IFT $(\mathrm{R}=0.364$, $P<0.005)$, DHEA $(\mathrm{R}=0.363, P<0.005)$, androstenedione $(\mathrm{R}=0.323, \quad \mathrm{P}<0.012)$, DHEAS $(\mathrm{R}=0.288$, $P<0.026)$ and testosterone $(\mathrm{R}=0.224, \mathrm{P}<0.080)$.

\section{Discussion}

The basic inclusion criterion was the presence of acne vulgaris. This criterion enabled us to form a group of patients with frequently elevated androgen levels and different grades of increased body hair.

The presence or grade of increased body hair was chosen as a clinical marker of hyperandrogenism. It is the only clinical symptom correlating well with the level of androgens. This correlation was also confirmed by our study. The results of Spearman's test demonstrated a highly significant correlation of FG-score with IFT and DHEA and a significant correlation of the FG-score with other androgens. This is an important argument supporting the essential role of androgen production in the clinical manifestation of increased body hair. 
Table 1 Summary of statistics and two sample comparisons in the groups of non-hirsute $(n=41)$ and hirsute $(n=20)$ women.

\begin{tabular}{|c|c|c|c|c|c|c|c|}
\hline & & Average & S.D. & Median & Minimum & Maximum & Mann-Whitney test \\
\hline $\begin{array}{l}\text { Age } \\
\text { (years) }\end{array}$ & $\begin{array}{l}\text { Non-hirsute } \\
\text { Hirsute }\end{array}$ & $\begin{array}{l}24.6 \\
26.5\end{array}$ & $\begin{array}{l}5.7 \\
5.9\end{array}$ & $\begin{array}{l}24.0 \\
27.0\end{array}$ & $\begin{array}{l}18.0 \\
16.0\end{array}$ & $\begin{array}{l}41.0 \\
42.0\end{array}$ & $\begin{array}{l}\text { NS } \\
P<0.120\end{array}$ \\
\hline $\begin{array}{l}\text { Body mass index } \\
\left(\mathrm{kg} / \mathrm{m}^{2}\right)\end{array}$ & $\begin{array}{l}\text { Non-hirsute } \\
\text { Hirsute }\end{array}$ & $\begin{array}{l}21.6 \\
23.9\end{array}$ & $\begin{array}{l}3.7 \\
3.9\end{array}$ & $\begin{array}{l}20.6 \\
23.3\end{array}$ & $\begin{array}{l}17.9 \\
19.4\end{array}$ & $\begin{array}{l}35.4 \\
34.9\end{array}$ & $P<0.005$ \\
\hline $\mathrm{IHA}$ & $\begin{array}{l}\text { Non-hirsute } \\
\text { Hirsute }\end{array}$ & $\begin{array}{l}3.49 \\
4.13\end{array}$ & $\begin{array}{l}0.98 \\
0.84\end{array}$ & $\begin{array}{l}3.48 \\
4.27\end{array}$ & $\begin{array}{l}1.64 \\
2.36\end{array}$ & $\begin{array}{l}5.73 \\
5.31\end{array}$ & ${ }^{* *}<0.006$ \\
\hline IFT & $\begin{array}{l}\text { Non-hirsute } \\
\text { Hirsute }\end{array}$ & $\begin{array}{r}3.3 \\
16.1\end{array}$ & $\begin{array}{r}2.8 \\
43.0\end{array}$ & $\begin{array}{l}2.9 \\
4.5\end{array}$ & $\begin{array}{l}0.2 \\
0.8\end{array}$ & $\begin{array}{l}12.5 \\
200\end{array}$ & $\begin{array}{l}\text { NS } \\
P<0.092\end{array}$ \\
\hline $\begin{array}{l}\text { Testosterone } \\
(\mathrm{nmol} / \mathrm{l})\end{array}$ & $\begin{array}{l}\text { Non-hirsute } \\
\text { Hirsute }\end{array}$ & $\begin{array}{l}1.81 \\
2.25\end{array}$ & $\begin{array}{l}0.83 \\
1.28\end{array}$ & $\begin{array}{l}1.60 \\
1.90\end{array}$ & $\begin{array}{l}0.30 \\
0.70\end{array}$ & $\begin{array}{l}3.95 \\
5.20\end{array}$ & $\begin{array}{l}N S \\
P<0.270\end{array}$ \\
\hline $\begin{array}{l}\text { Androstenedione } \\
\text { (nmol/l) }\end{array}$ & $\begin{array}{l}\text { Non-hirsute } \\
\text { Hirsute }\end{array}$ & $\begin{array}{r}8.9 \\
12.1\end{array}$ & $\begin{array}{l}3.5 \\
5.6\end{array}$ & $\begin{array}{r}8.4 \\
10.0\end{array}$ & $\begin{array}{l}2.9 \\
3.4\end{array}$ & $\begin{array}{l}16.5 \\
28.2\end{array}$ & ${ }^{*} P<0.017$ \\
\hline $\begin{array}{l}\text { DHEAS } \\
(\mu \mathrm{mol} / \mathrm{l})\end{array}$ & $\begin{array}{l}\text { Non-hirsute } \\
\text { Hirsute }\end{array}$ & $\begin{array}{l}6.1 \\
7.4\end{array}$ & $\begin{array}{l}2.9 \\
3.1\end{array}$ & $\begin{array}{l}5.7 \\
6.8\end{array}$ & $\begin{array}{l}1.7 \\
3.0\end{array}$ & $\begin{array}{l}14.5 \\
13.5\end{array}$ & $\begin{array}{l}\text { NS } \\
P<0.085\end{array}$ \\
\hline $\begin{array}{l}\text { DHEA } \\
(\mathrm{nmol} / \mathrm{l})\end{array}$ & $\begin{array}{l}\text { Non-hirsute } \\
\text { Hirsute }\end{array}$ & $\begin{array}{l}6.7 \\
8.0\end{array}$ & $\begin{array}{l}4.0 \\
3.1\end{array}$ & $\begin{array}{l}5.5 \\
6.9\end{array}$ & $\begin{array}{l}2.3 \\
3.0\end{array}$ & $\begin{array}{l}17.3 \\
16.8\end{array}$ & ${ }^{*} P<0.043$ \\
\hline $\begin{array}{l}\text { SHBG } \\
(\mathrm{nmol} / \mathrm{l})\end{array}$ & $\begin{array}{l}\text { Non-hirsute } \\
\text { Hirsute }\end{array}$ & $\begin{array}{l}85 \\
56\end{array}$ & $\begin{array}{l}52 \\
37\end{array}$ & $\begin{array}{l}64 \\
57\end{array}$ & $\begin{array}{r}24 \\
1\end{array}$ & $\begin{array}{l}219 \\
146\end{array}$ & $\begin{array}{l}\text { NS } \\
P<0.096\end{array}$ \\
\hline
\end{tabular}

${ }^{\star} P<0.05,{ }^{*} P<0.01$, NS, not significant.

Table 2 Contingency tables of the presence of hirsutism in women with normal and elevated markers of hyperandrogenism.

\begin{tabular}{|c|c|c|c|}
\hline Marker & Hirsutism & $\begin{array}{c}\text { Below } \\
\text { cut-off value }\end{array}$ & $\begin{array}{c}\text { Above } \\
\text { cut-off value }\end{array}$ \\
\hline $\begin{array}{l}\text { IHA } \\
* *(P<0.002)\end{array}$ & $\begin{array}{l}\text { Non-hirsute } \\
\text { Hirsute }\end{array}$ & $\begin{array}{l}39 \\
62.90 \% \\
13 \\
20.97 \%\end{array}$ & $\begin{array}{l}2 \\
3.23 \% \\
8 \\
12.90 \%\end{array}$ \\
\hline $\begin{array}{l}\text { IFT } \\
\text { NS }(P<0.1)\end{array}$ & $\begin{array}{l}\text { Non-hirsute } \\
\text { Hirsute }\end{array}$ & $\begin{array}{l}29 \\
46.77 \% \\
10 \\
16.13 \%\end{array}$ & $\begin{array}{l}12 \\
19.35 \% \\
11 \\
17.74 \%\end{array}$ \\
\hline $\begin{array}{l}\text { Testosterone } \\
\text { NS }(P<0.11)\end{array}$ & $\begin{array}{l}\text { Non-hirsute } \\
\text { Hirsute }\end{array}$ & $\begin{array}{l}35 \\
56.45 \% \\
14 \\
22.58 \%\end{array}$ & $\begin{array}{l}6 \\
9.68 \% \\
7 \\
11.29 \%\end{array}$ \\
\hline $\begin{array}{l}\text { Androstenedione } \\
\text { NS }(P<0.15)\end{array}$ & $\begin{array}{l}\text { Non-hirsute } \\
\text { Hirsute }\end{array}$ & $\begin{array}{l}8 \\
12.90 \% \\
1 \\
1.61 \%\end{array}$ & $\begin{array}{l}33 \\
53.23 \% \\
20 \\
32.26 \%\end{array}$ \\
\hline $\begin{array}{l}\text { DHEAS } \\
\text { NS }(P<0.26)\end{array}$ & $\begin{array}{l}\text { Non-hirsute } \\
\text { Hirsute }\end{array}$ & $\begin{array}{l}30 \\
48.39 \% \\
12 \\
19.35 \%\end{array}$ & $\begin{array}{l}11 \\
17.74 \% \\
9 \\
14.52 \%\end{array}$ \\
\hline $\begin{array}{l}\text { DHEA } \\
\text { NS }(P<1)\end{array}$ & $\begin{array}{l}\text { Non-hirsute } \\
\text { Hirsute }\end{array}$ & $\begin{array}{l}34 \\
54.84 \% \\
17 \\
27.42 \%\end{array}$ & $\begin{array}{l}7 \\
11.29 \% \\
4 \\
6.45 \%\end{array}$ \\
\hline
\end{tabular}

NS, not significant.
We are also well aware that the presence or grade of increased body hair is influenced by the individual reaction of pilosebaceous units on androgens. However, this limitation is present with all laboratory markers and should not have an effect when comparing them.

Besides the commonly assayed androgens and IFT, a new index referred to as IHA has been reported. The IHA calculated the levels of androgen precursors and IFT, thus allowing us to take into consideration total androgen production and the level of SHBG. The calculation of IHA is simple and helpful for clinical practice.

The results of all statistical tests showed the strongest relationship between the presence of hirsutism or body hair grade and the value of IHA. The most significant difference between hirsute and non-hirsute women was found in the mean value of this marker. IHA was the only marker whose value exceeding the upper reference limit was reported significantly more frequently in hirsute women. Spearman's test demonstrated the strongest correlation between the value of IHA and the FG-score.

Our results clearly showed that the best correlation with the clinical marker of hyperandrogenism exists with IHA, an index which, we suggest, takes into account the levels of all commonly determined androgens and SHBG. Determination of the levels of a single androgen or calculation of the value of free testosterone seems to be less indicative of androgen production. By virtue of its simple and rapid calculation, IHA may become an important tool in the diagnosis of hyperandrogenism. 


\section{Acknowledgements}

This work was supported by Grants No. VZ J13/ 98:111100005 and No. 4290-3 of the Internal Grant Agency of the Ministry of Health of the Czech Republic.

\section{References}

1 Conway GS \& Jacobs HS. Clinical implications of hyperinsulinaemia in women. Clinical Endocrinology 199339 623-632.

2 Ehrman DA, Sturis J, Byrne MM, Karrison T, Rosenfield RL \& Polonsky KS. Insulin secretory defects in polycystic ovary syndrome. Relationship to insulin sensitivity and family history of non-insulin dependent diabetes mellitus. Journal of Clinical Investigation 199596 520-527.

3 Dunaif A \& Finegood DT. Beta-cell dysfunction independent of obesity and glucose intolerance in the polycystic ovary syndrome. Journal of Clinical Endocrinology and Metabolism 199681 942-947.

4 Talbott E, Guzick D, Clerici A, Berga S, Detre K, Weimer K et al. Coronary heart disease risk factors in women with polycystic ovary syndrome. Arteriosclerosis Thrombosis and Vascular Biology $199515821-826$

5 Talbott E, Clerici A, Berga SL, Kuller L, Guzick D, Detre K et al. Adverse lipid and coronary heart disease risk profiles in young women with polycystic ovary syndrome: results of a case-control study. Journal of Clinical Epidemiology 199851 415-422.

6 Robinson S, Henderson AD, Gelding SV, Kiddy D, Niththyananthan R, Bush A et al. Dyslipidemia is associated with insulin resistance in women with polycystic ovaries. Clinical Endocrinology $199644277-284$.

7 Rajkhowa Z, Neary RH, Kumptala P, Game FL, Jones PW, Odhrai MS et al. Altered composition of high density lipoproteins in women with the polycystic ovary syndrome. Journal of Clinical Endocrinology and Metabolism 199782 33893394.
8 Atiomo WU, Bates SA, Condon JE, Shaw S, West JH, Prentice AG et al. The plasminogen activator system in women with polycystic ovary syndrome. Fertility and Sterility 199869 236-241.

9 Dahlgren E, Johansson S, Lindstedt G, Knutsson F, Oden A, Janson PO, et al. Women with polycystic ovary syndrome wedge resected in 1956 to 1965: a long term follow-up focusing on natural history and circulating hormones. Fertility and Sterility 199257 505-513.

10 Dahlgren E, Janson PO, Johansson S, Lapidus L, Lindstedt G, Tengborn L et al. Hemostatic and metabolic variables in women with polycystic ovary syndrome. Fertility and Sterility 199461 455-460.

11 Cibula D, Cifkova R, Fanta M, Poledne R, Zivny J \& Skibova J. Increased risk of non-insulin dependent diabetes mellitus, arterial hypertension and coronary artery disease in perimenopausal women with a history of the polycystic ovary syndrome. Human Reproduction 200015 785-789.

12 Govind A, Obhrai MS \& Clayton RN. Polycystic ovaries are inherited as an autosomal dominant trait: analysis of 29 polycystic ovary syndrome and 10 control families. Journal of Clinical Endocrinology and Metabolism 199984 38-43.

13 Legro RS, Driscoll D, Strauss JF III, Fox O \& Dumaif A. Evidence for a genetic basis for hyperandrogenemia in polycystic ovary syndrome. PNAS 199895 14956-14960.

14 Urbanek M, Legro RS, Driscoll DA, Azziz R, Ehrmann DA, Norman RJ et al. Thirty-seven candidate genes for polycystic ovary syndrome: strongest evidence for linkage is with follistatin. PNAS $1999968573-8578$.

15 Franks S, Gharani N \& McCarthy M. Genetic abnormalities in polycystic ovary syndrome. Annals of Endocrinology 199960 $131-133$.

16 Ferriman D \& Gallwey JD. Clinical assessment of body hair growth in women. Journal of Clinical Endocrinology and Metabolism $1961211440-1447$.

Received 14 January 2000

Accepted 29 May 2000 